\title{
Long-term sediment loading trends in the Paradise Creek watershed
}

\author{
E.S. Brooks, J. Boll, A.J. Snyder, K.M. Ostrowski, S.L. Kane, J.D. Wulfhorst, L.W. Van Tassell, and \\ R. Mahler
}

\begin{abstract}
The Northwest Wheat and Range Region is historically known for high soil erosion rates. During the $1920 \mathrm{~s}$ and $1930 \mathrm{~s}$, erosion rates of 200 to $450 \mathrm{t} \mathrm{ha}^{-1}$ (90 to $200 \mathrm{tn} \mathrm{ac}^{-1}$ ) in a single winter season were observed. Improved soil conservation practices over the last 80 years have significantly reduced soil erosion rates, yet there is scarce evidence of significant reductions in sediment loading delivered by streams in the region. In this paper, detailed monitoring data collected in the Paradise Creek watershed, located in the high precipitation zone of the Northwest Wheat and Range Region in north central Idaho, provided an opportunity to assess the impacts of management practices on sediment loading at the watershed outlet. Both detailed event-based sampling over the last eight years and three day per week grab samples collected over the last 28 years indicate a statistically significant decreasing trend in overall sediment load. This decreasing sediment load can be attributed primarily to conversion from conventional tillage systems to minimum tillage and perennial grasses through the Conservation Reserve Program, practices initiated in the late 1970s and early 1980s. Over the last 10 years (1999 to 2009), management practices have targeted gully erosion and stream bank failures. Upstream and downstream sampling shows a larger than expected increase in sediment load through the urban areas of the watershed. Preliminary modeling results and empirical evidence indicate that delayed reduction in sediment load at the watershed outlet and the increased sediment load through the lower urban portion of the watershed may be caused by sediment storage in the stream channel.
\end{abstract}

Key words: conservation practices—conservation tillage—-stream erosion-time lag

\begin{abstract}
Water quality in the nation's surface water and groundwater is a continuing environmental concern. Nonpoint source pollution is thought to be the primary mechanism for water pollution, originating in uplands of agricultural, forest, and urban land uses. Following the 2002 farm bill, the USDA established the Conservation Effects Assessment Project (CEAP) watershed studies to improve the understanding of conservation farming practices by using a watershed perspective instead of a plot- or field-scale perspective. In 2004, the USDA Cooperative State Research, Education, and Extension Service initiated the CEAP competitive watershed program with strong emphasis on understanding the effects of location and timing of conservation efforts within a watershed on overall pollutant loading at the outlet of the watershed.Watersheds selected in the USDA Cooperative State
\end{abstract}

the watershed exhibited excessive ammonia, total phosphorus, sediment, temperature, and pathogens. A Total Maximum Daily Load (TMDL) was developed for PCW in 1997 (IDEQ 1997), which required a 75\% reduction in sediment load at the outlet of the watershed. A plan to address the pollutant sources in the PCW was completed in 1999 (PCWAG 1999), and was implemented from 1999 to 2003 (PCWAG 2004).

History of Soil Erosion on the Palouse. The NWRR, also referred to as the Palouse region of the Inland Northwest, encompasses a $20,000 \mathrm{~km}^{2}\left(7,700 \mathrm{mi}^{2}\right)$ area in eastern Washington, northeastern Oregon and northern Idaho (Busacca 1989). This region is renowned for its productive dryland winter wheat, dry peas, and lentils, yet cultivation of these crops on long, steep slopes of the Palouse has resulted in excessive soil erosion.

Soil erosion research in the region began in 1930 with the establishment of the Palouse Conservation Experiment Station. The average annual water erosion rates documented by the Soil Conservation Service in Whitman County, Washington, by annual field surveys of water erosion damage at the end of each winter from 1939 to 1960 was $45 \mathrm{t} \mathrm{ha}^{-1}$ (20 tn $\mathrm{ac}^{-1}$ ) (Kaiser 1961). It was estimated that, on average, 18 million $\mathrm{t}$ (20 million $\mathrm{tn})$ of soil were lost each year. In highly productive years during this period, the county produced approximately 540,000 t (20 million $\mathrm{bu}$ ) of wheat. Therefore, on average, $33 \mathrm{t}$ of soil was lost for every tonne of wheat produced (i.e., a ton of soil was lost for every bushel of wheat produced).

In 1978, the average annual erosion rate on cultivated cropland for the Palouse River basin was $31 \mathrm{t} \mathrm{ha}^{-1}\left(14 \mathrm{tn} \mathrm{ac}^{-1}\right)$ (USDA 1978). Some slopes had erosion rates of 200 to 450 $\mathrm{t} \mathrm{ha}^{-1}$ (90 to $200 \mathrm{tn} \mathrm{ac}^{-1}$ ) in a single winter the watershed outlet.

Paradise Creek watershed (PCW) was selected as one of the original four watershed studies funded by CEAP in 2004 (figure 1). The PCW is located in the eastern, high precipitation zone of the Northwest Wheat and Range Region (NWRR) (Austin 1981) in northern Idaho, which is known for its historic excessive erosion. Although soil conservation research dates back to 1930 in the NWRR, renewed emphasis was placed on reducing sediment loading at the outlet of the PCW after Paradise Creek was listed as an impaired water body for cold water biota, secondary contact recreation, and agricultural water supply in 1994. Monitoring data indicated the stream water at the outlet of
Erin S. Brooks is a research scientist, Jan Boll is a professor, and Andre J. Snyder is a senior research technician in the Biological and Agricultural Engineering department at the University of Idaho, Moscow, Idaho. Krzysztof M. Ostrowski is the senior environmental specialist at Arcadis, Warsaw, Poland. Stephanie Kane is manager of the Social Science Research Unit, J.D. Wulfhorst is an associate professor in Agricultural Economics and Rural Sociology, and Robert Mahler is a professor in Plant, Soil, and Entomological Sciences at the University of Idaho, Moscow, Idaho. Larry W. Van Tassell is a professor and department head of the Department of Agricultural Economics, University of Nebraska, Lincoln, Nebraska. 


\section{Figure 1}

Location of detailed water quality monitoring sites in the Paradise Creek watershed.

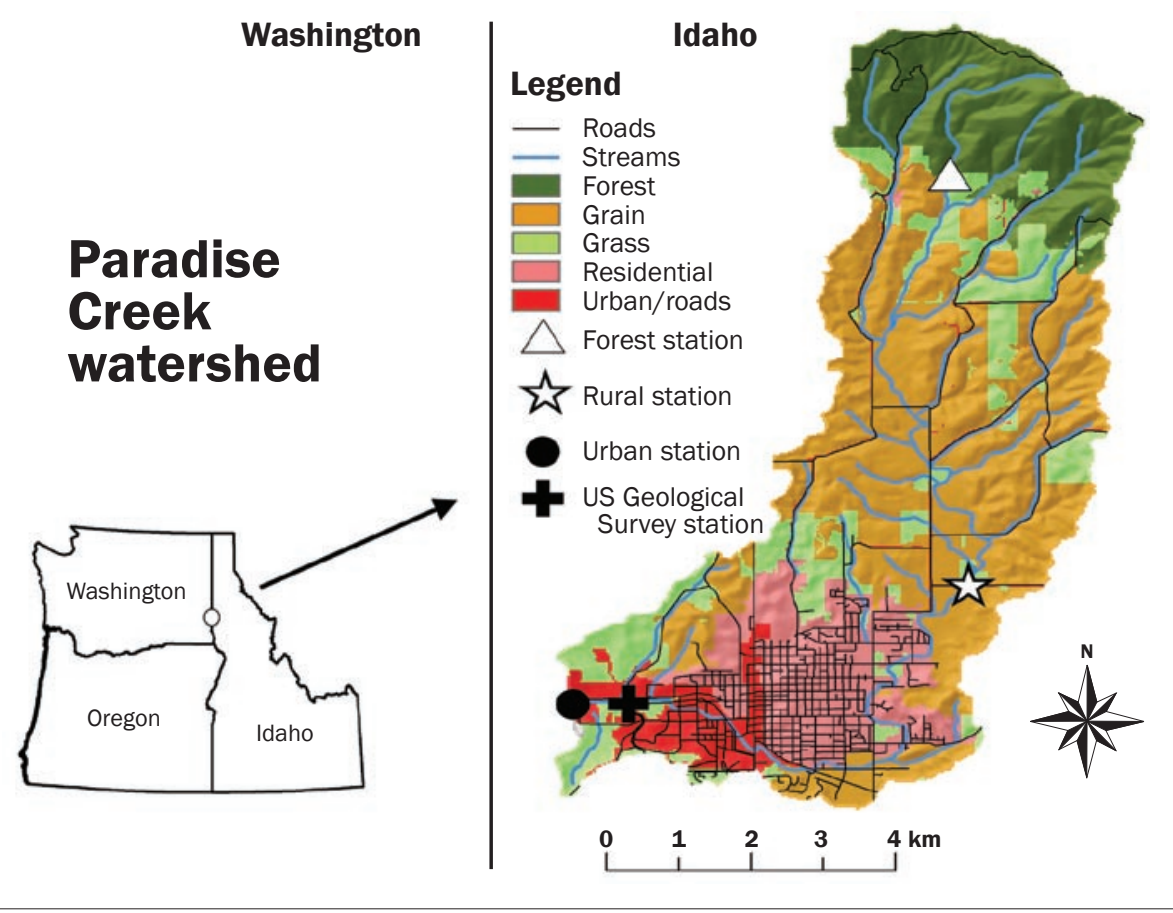

season. Since the region was first cultivated about 100 years ago, all the original topsoil had been lost from $10 \%$ of the cropland, and one-fourth to three-fourths of the original topsoil had been lost from $60 \%$ of the cultivated area in the basin (USDA 1978).

Although most erosion today is caused by surface runoff, Kaiser (1961) indicated that tillage erosion was the dominant problem before 1960. Tillage erosion occurs when the furrow from a moldboard plow or oneway disc is thrown downhill. Kaiser (1961) dramatically showed through pictures of the edge of a particular field that tillage erosion resulted in $0.75 \mathrm{~m}(2.5 \mathrm{ft})$ of soil loss from

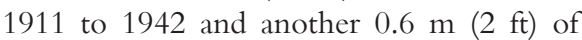
soil loss by 1959 . Farmers who continue to use moldboard plows recognize this problem and plow in a direction that ensures the plow furrow is thrown uphill rather than downhill. Remnants of historic tillage erosion can still be seen around the Palouse today.

This excessive erosion has negatively impacted wheat yields in the Palouse region. Active winter wheat farming began in the region in the late 1880 s. Initial crop yields were as high as $4.7 \mathrm{t} \mathrm{ha}^{-1}\left(70 \mathrm{bu} \mathrm{ac} \mathrm{ar}^{-1}\right)$ on the original high organic matter and nutrient-rich soils recently converted from highly productive shortgrass prairie (USDA 1978). These early wheat yields from unfertilized soils were close to the average yields currently obtained in Whitman county in heavily fertilized cropping systems (USDA NASS 2009). By 1910, much of the nutrients and organic matter had been lost through burning stubble, summer fallow practices, and excessive tillage, resulting in average winter wheat yields in the state of Washington of only $1.2 \mathrm{t} \mathrm{ha}^{-1}$ (18 bu ac $\mathrm{bu}^{-1}$ ) (USDA NASS 2009). Kaiser (1967) measured extreme variability in soil erosion and wheat yields across transects within specific fields and showed that areas with the most severe erosion had the lowest wheat yields. Hilltops and steep north-facing slopes had the greatest erosion rates, with winter wheat yields approximately one-third of the yields observed on noneroded lower foot slopes. These excessively eroded hilltops, termed "clay knobs," are still noticeable today as the lighter colored, clay subsoil horizons remain exposed and contrast with the adjacent darker silt loam topsoils.

Despite the extreme loss of topsoil, overall wheat yields in the region have gradually increased since 1910, with improved varieties of wheat and more efficient use of commercial fertilizers. Shortly after 1910, farmers in the NWRR recognized the importance of adding legume crops (e.g., alfalfa, clover, peas) into the crop rotation to increase soil fertility and later, in the 1950s, abandoned alfalfa and clover when commercial fertilizers became available. Improved varieties of wheat over the last 30 years have brought yields back up to the original $4.7 \mathrm{t} \mathrm{ha}^{-1}\left(70 \mathrm{bu} \mathrm{ac}^{-1}\right)$. Although wheat yields have increased, it was estimated that average yields in 1978 could have been $20 \%$ higher if erosion from previous years had been controlled (USDA 1978).

Recent assessments provide evidence of decreasing soil erosion within the Palouse basin (McCool and Roe 2005). Figure 2, taken from McCool and Roe (2005), shows a decreasing trend in soil erosion rates measured by Verl Kaiser while working for the Soil Conservation Service from 1940 to 1972 and extended by Don McCool while working for the USDA Agricultural Research Service from 1973 to 1982 . Soil erosion rates were appraised by means of annual field observations after the runoff season on 500 to 1,000 fields (Kaiser 1967). As shown in figure 2 and described by McCool and Roe (2005), the years with the greatest soil erosion were typically associated with soil freezing events, when soil infiltration rates are greatly reduced, resulting in severe runoff on saturated soils.

Much of the conversion to more conservation practices over the last 30 years can be attributed to cooperative research and extension funded through a regional organization called Solutions to Environmental and Economic Problems (STEEP) - a collaboration among state agricultural experiment stations (Idaho, Oregon, and Washington) and the USDA Agricultural Research Service. The idea for STEEP was initially proposed and developed by the wheat growers in the region, who realized the detrimental effects of erosion on crop yields. Upon the inception of STEEP in 1975, initial research objectives focused on the need for reduced erosion through alternative tillage practices and new wheat varieties. The STEEP organization funded much of the research, education, and extension critical for development and adoption of innovative crop and soil management techniques (STEEP 2007). A recent publication highlights the critical achievements of STEEP (STEEP 2007), including the development of direct seed and minimum tillage systems, which are economically profitable, maintain competitive yields, and greatly reduce erosion.

Historic conventional tillage, prior to the 1980s, often required eight or more passes with a moldboard plow, disc, and field cultivator when preparing a seedbed for a spring 


\section{Figure 2}

Average annual erosion manually measured each spring on 500 to 1,000 fields in the Northwest Wheat and Range Region, used with permission from McCool and Roe (2005). Filled points represent years where erosion occurred on frozen soil.

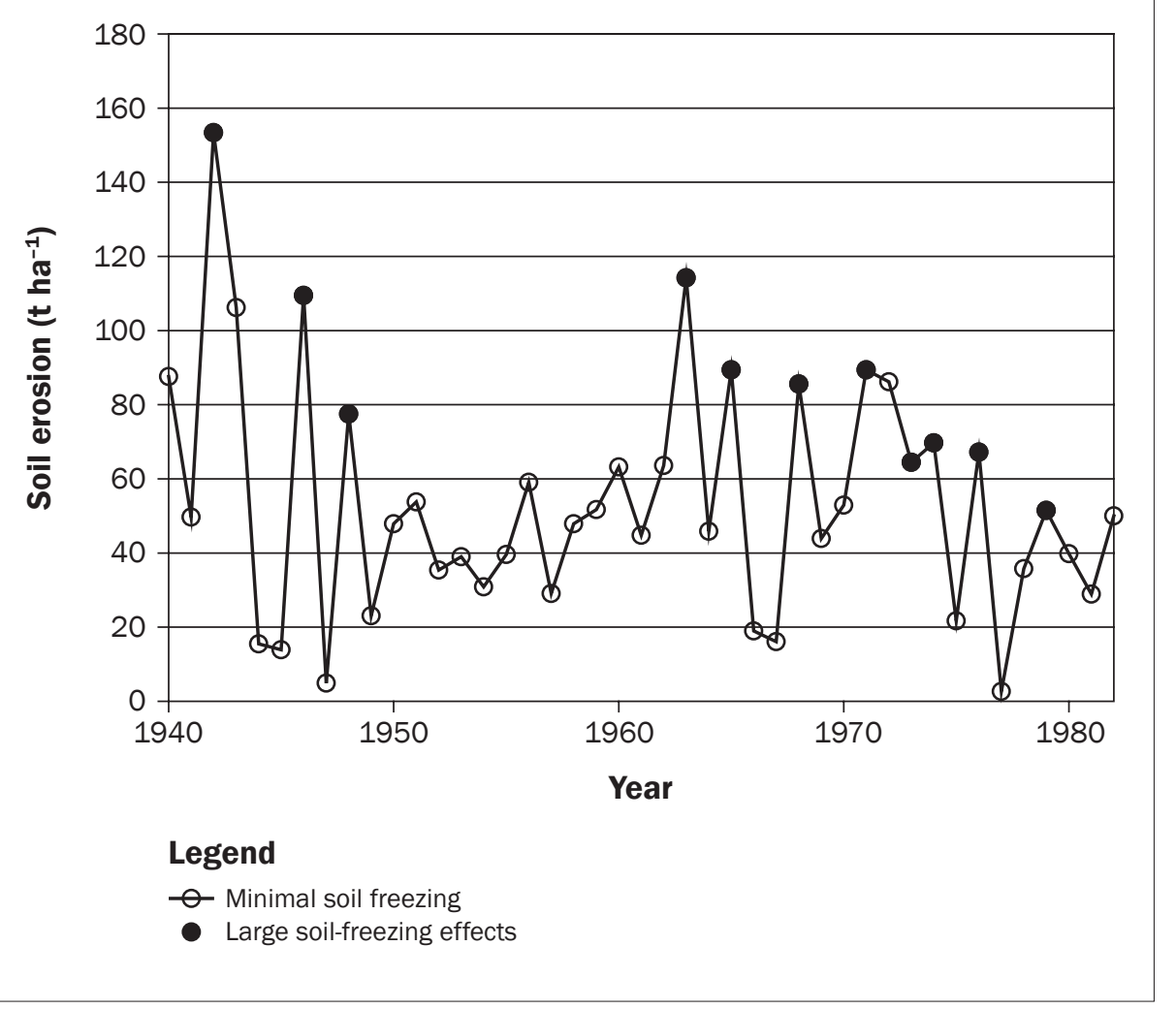

crop following winter wheat and four to five passes when preparing for a winter wheat crop following spring grain (STEEP 2007). In contrast, conservation tillage has reduced the number of passes to three or four, and the technique primarily utilizes the chisel plow and field cultivator-implements that leave much more of the crop residue on the soil surface than the moldboard plow. Furthermore, most seeders can now plant through pea residue, eliminating the need for tillage when transitioning to winter wheat.

Although summer fallow is still practiced today in the drier regions of the NWRR, it has been almost eliminated in the high precipitation zone, where soil moisture is sufficient for continuous cropping systems. It was estimated that approximately $13 \%$ of the high precipitation zone in the 1970s was fallowed. This percentage dropped to $6 \%$ in the $1990 \mathrm{~s}$ and to near zero in 2005 (STEEP 2007).

Historically, residue management in the region also included burning wheat stubble. In the high precipitation zone of the NWRR during the 1970 s, approximately $36 \%$ of the stubble was burned before plowing. This percentage declined to $22 \%$ in 1990 and was eliminated by 2005 (STEEP 2007).

The STEEP was a key organization assisting farmers in securing incentive payments for erosion and water quality control following the Food Security Act of 1985. Based on the Revised Universal Soil Loss Equation Version 2 (RUSLE2) model simulations, soil erosion in the Palouse Basin reduced approximately $75 \%$ from 1975 to 2005 due to the transition to more conservation tillage practices (STEEP 2007).

Although the reduction in soil erosion across the basin seems fairly clear, few data are available to document long-term trends in overall sediment loading delivered by streams in the Palouse Basin. The mostly widely available dataset is sediment loading data recorded by the US Geologic Survey from 1962 to 1971 and again from 1993 to 1996 at the outlet of the Palouse basin near Hooper, Washington. Ebbert and Roe (1998) examined this dataset and showed that although the record is biased by a few extreme events, the average annual sediment yield for the 1993 to 1996 period (10 tha- $\mathrm{m}^{-1}$ [1.4 tn ac- $\left.\mathrm{ft}^{-1}\right]$ ) was half the average annual sediment yield for the 1962 to 1971 period (21 t ha- $\mathrm{m}^{-1}$ [2.8 tn ac- $\left.\left.\mathrm{ft}^{-1}\right]\right)$. However, no analysis was associated with this study to determine statistical significance.

In both the Ebbert and Roe (1998) and McCool and Roe (2005) studies, the decreasing trend in soil erosion and sediment yield was attributed largely to a transition to more conservation tillage practices. $\mathrm{McCool}$ and Roe (2005) also noted a general decreasing trend in the number of frozen soil runofferosion events in recent years, which may also contribute to the observed reductions in erosion and sediment yields.

2000 to 2003 Paradise Creek Watershed Restoration. From 1999 to 2003,\$1.8 million were spent improving management practices within PCW (PCWAG 2004). Roughly half this money was provided through US Environmental Protection Agency 319 grants, with the remaining matching funds provided by state soil and water improvement grants and volunteer labor. Implementation of these practices occurred under the guidance of the Latah County Soil and Water Conservation District and a nonprofit organization called the Palouse Clearwater Environmental Institute. Table 1 describes how this money was spent by major land use in the watershed. Improvements in the agricultural region focused on conversion to direct seed/highresidue practices, elimination of gully erosion using water and sediment control structures called "gully plugs" (Idaho Natural Resources Conservation Service Conservation Practice Standard 638), stabilization of stream banks, and restoration of riparian areas. The primary focus of restoration in the urban areas was focused on streambank stabilization and restoration of riparian areas. Streambank stabilization practices ranged from complete remeander of the stream channel with large revetments (e.g., log crib, root wad) to resloping streambanks and toe-slope stabilization with banks covered in erosion-control fabric and soil-wrap revetments. Riparian restoration involved weed control and planting native grasses, herbaceous plants, and woody species. Overall, $7.1 \mathrm{~km}(4.4 \mathrm{mi})$ and $7.4 \mathrm{~km}$ (4.6 mi) of stream bank were restored in the urban region and rural regions, respectively. This represents $45 \%$ and $17 \%$ of the entire stream length in the urban and rural regions, respectively. Restoration in the forested region and the county roads focused on reducing road erosion and cutbank failures. Overall, $43 \%$ of the total money was spent on 


\section{Table 1}

Description of management practices installed between 2000 to 2003 in the Paradise Creek watershed.

\begin{tabular}{lcc}
\hline Description & Amount & Cost \\
\hline Rural region & & \\
\hline Riparian buffer & $8.5 \mathrm{ha}$ & \\
Gully plugs & 19 & \\
Structural improvements (e.g., rock chutes) & $552 \mathrm{ha}$ & $\$ 900,000$ \\
Conversion to direct seed/high residue management & $7.4 \mathrm{~km}$ & \\
Stream bank stabilization & $14.1 \mathrm{ha}$ & \\
Riparian restoration (i.e. brush/tree seedings) & $1.4 \mathrm{ha}$ & \\
Wetland restoration & & $\$ 36,000$ \\
\hline Forested region & $2.4 \mathrm{~km} *$ \\
\hline Installation of cross drains & $2.4 \mathrm{~km}$ & \\
Rock road surface & & $\$ 77,000$ \\
\hline County roads & $670 \mathrm{~m}$ & \\
\hline Stabilize eroding cut banks & 2 & \\
Stabilize eroding bridge crossings & & \\
\hline Urban region & $7.1 \mathrm{~km}$ & \\
\hline Stream bank stabilization & $6.5 \mathrm{ha}$ & \\
Riparian restoration & $655 \mathrm{~m}^{2}$ & \\
Wetland restoration & & \\
\hline
\end{tabular}

* The number of cross drains depended on local slope and road surface conditions.

improvements in the urban region, $2 \%$ was spent in the forest region, $50 \%$ was spent in the agriculture-dominated rural region, and $5 \%$ was spent on improving county roads. In addition to the restoration funded through 319 grants, 356 ha $(879$ ac) of highly erodible cropland was enrolled in the Conservation Reserve Program.

Objectives. The PCW CEAP project focused on assessing the effectiveness of management practices at reducing the excessive sediment loading at the outlet of the watershed. In this paper, long-term monitoring data at the outlet of the watershed (1980 to 2008) and detailed event-based monitoring data collected at multiple locations within PCW (2001 to 2008) were used to address the following CEAP objectives:

1. Assess the effectiveness of management practices used in the watershed over the past 30 years at reducing sediment loading at the outlet of the PCW watershed.

2. Use monitoring data to identify the primary sources of sediment within the PCW watershed.

\section{Materials and Methods}

Watershed Description. The PCW (4,890 ha [18.9 $\left.\mathrm{mi}^{2}\right]$ ) is located in the Palouse River hydrologic basin in northern Idaho. The 2003 land-use distribution in the PCW by total watershed area is $62 \%$ rural, $20 \%$ urban, and 18\% forest (see figure 1). Paradise Creek (HUC 17060108) flows through a landform dominated by moderately steep to steep rolling hills, with the steepest slopes (up to 50\%) in the upper portion of the watershed. Elevations range from $1,330 \mathrm{~m}(4,360 \mathrm{ft})$ at the headwaters to $770 \mathrm{~m}(2,500 \mathrm{ft})$ at the PCW outlet for this study, established approximately $1 \mathrm{~km}$ $(0.6 \mathrm{mi})$ east of the Idaho-Washington state border (4643'54.500"N; $\left.117^{\circ} 02^{\prime} 04.297^{\prime \prime W}\right)$. Average annual precipitation (1971 to 2000) ranges from $650 \mathrm{~mm}$ (26 in) at the outlet to $1,000 \mathrm{~mm}$ (39 in) at the highest elevation, with approximately $70 \%$ falling as rain or snow from November to May (McDaniel et al. 2001). Soils in the mostly forested upland areas consist of deep, well-drained gravelly silt loams formed in volcanic ash, loess, and granitic residuum. Soils in the agricultural upland areas are deep to very deep, moderately well-drained to well-drained silt loams formed in loess. These upland soils often have argillic horizons, leading to seasonally perched water tables (November to May), high subsurface lateral flow, and frequently saturated toeslopes (McDaniel et al. 2001). Lowland areas in both the agricultural and urban portions of the PCW are relatively flat and generally have very deep, somewhat poorly drained soils formed in alluvium, with frequent elevated water tables (February to June) (Barker 1981).
In the forested headwaters of Paradise Creek, stream gradients are relatively high (average 7\%) (IDEQ 1997), and the channel bed and banks are mostly comprised of granitic sand, gravel, cobbles, and boulders, with some volcanic ash and loess intermixed. The forest upland and riparian areas are heavily vegetated with native second-growth coniferous trees and associated understory shrubs, grasses, and forbs. Scattered lowdensity residences, nonmotorized recreation trails, and minimally used logging roads are the dominant anthropogenic features in the forested area of the PCW. In the agricultural area, Paradise Creek is generally medium gradient $(0.5 \%)$ and contains clay and siltsized bed and bank material. The majority of agricultural upland and riparian areas are heavily cultivated, often within $<1 \mathrm{~m}(<3 \mathrm{ft})$ of the streambank. Additionally, low-density residential development and rural roads are found throughout the agricultural area. In the urban portion of the PCW, stream gradients are lower (0.01\%) with upland and riparian areas dominated by residential and commercial developments with untreated storm sewers. In the lower reaches of the urban areas, streambed and bank substrates often consist of basalt bedrock and more coarse-grained sediments. Throughout the agricultural and urban reaches of Paradise Creek, dense stands of nonnative reed canary grass (Phalaris arundinacea) in the channel are common and encourage sediment deposition and/or redirection of flow energy from the main channel toward stream banks. In general, streambanks in both the agricultural and urban reaches of Paradise Creek are often vertical, with occasional bank slumping and erosion.

The most profitable crop in the region is soft white winter wheat, which is grown in two- or three-year rotations. Two-year crop rotations typically include fall-planted winter wheat followed by a spring grain, either spring wheat or spring barley. Threeyear crop rotations typically include winter wheat, followed by spring wheat or barley, followed by peas or lentils. Over the last 30 years, most farmers in the PCW, which lies within the high precipitation zone of the NWRR, have transitioned from conventional tillage, where stubble was burned and crop rotations included a summer fallow season, to conservation tillage practices, where burning and summer fallow has been eliminated. Most cropped land is maintained with 
greater than 30\% residue cover. Dry peas and lentil crops are harvested low to the ground, and therefore, leave the least amount of surface residue cover. Occasionally, frozen soil conditions can contribute to heavy erosion, especially during rain-on-snow events. The combination of steep cultivated slopes, erodible surface soils, perched water tables, snow-drifting, and frozen-soil phenomena support high erosion potential in the PCW.

Sediment Load Monitoring. Long-term trends in sediment loading from Paradise Creek are assessed using two primary datasets. The first utilized daily US Geologic Survey streamflow data and three-day per week total suspended sediment (TSS) grabsample data collected by the city of Moscow Waste Water Treatment Plant (MWWTP) from 1979 to 2008 at the outlet of the PCW upstream of the MWWTP discharge point. The second dataset was based on detailed, event-based monitoring data dating back to 2001 collected at three locations within the watershed. The three monitoring stations were selected to isolate the long-term trends from the major land uses in the PCW. These stations were installed at the following locations: (1) at the downstream edge of the predominately forest land use in a headwater tributary (forest), (2) at the downstream edge of rural land use (rural), and (3) at the downstream edge of urban land use (urban) (figure 1). The forest station monitored streamflow and water quality from a 161 ha (398 ac) completely forested catchment with minimal disturbances. The rural station monitored a 2,930 ha $(7,241 \mathrm{ac})$ catchment, of which $30 \%$ was forested, $69 \%$ was in agriculture, and $1 \%$ was composed of roads and residential houses. The urban station monitored the cumulative effect of the entire 4,890 ha $(12,084 \mathrm{ac})$ watershed. The methodologies used to calculate sediment load follow.

Moscow Waste Water Treatment Plant Grab-Sample Data. Prior to 2002, the only available detailed water quality data in the PCW were collected by the MWWTP. Grab samples were collected by dipping a bottle in the stream at 8:00 a.m. local time, three days per week at a location approximately $20 \mathrm{~m}$ (66 ft) upstream of the wastewater discharge point. Often during major storm events, samples were collected once a day. These samples were analyzed for TSS concentration using vacuum filtration standard method 2540D (Eaton et al. 1995). These data were collected from 1979 to 1980 and again from
1988 to the present time. Daily streamflow records also date back to 1979 through a US Geologic Survey stream gage station located roughly $1 \mathrm{~km}$ (0.6 mi) upstream of the existing urban monitoring station. Total suspended sediment concentrations on days without observed data were calculated based on linear interpolation between successive TSS measurements and streamflow. Excessive extrapolation on peak events with limited data was manually screened by comparing extrapolated values to yearly TSS/streamflow regressions. Sediment load was calculated as the summation of TSS multiplied by flow for the entire year.

Event-Based Monitoring Data. Sediment loads for the 2002 to 2008 water years (WY) at the urban and rural detailed, eventbased monitoring stations were based on 15-minute average turbidity, event-based TSS measurements, and observed streamflow. Instantaneous 15-minute average stage height was recorded with pressure sensors installed in stilling wells (Druck Inc., Houston, Texas; Instrumentation Northwest, Kirkland, Washington). Instantaneous 15minute average turbidity was measured with OBS-3 IR sensors (D\&A Instrument Co, Port Townsend, Washington). Manual discharge measurements (velocity-area method) at each location were used to develop and maintain stage height-discharge rating curves to calculate 15-minute average stream discharge. Water samples at both the rural and urban locations were collected with an ISCO 3700 sampler interfaced with a CR10X datalogger (Campbell Scientific, Logan, Utah). Automated event-based samples were collected at established stream stage height thresholds, flow volume thresholds, or a combination of both. Occasional manual samples and weekly samples during baseflow periods were used to supplement the automated event-based samples. The turbidity probe and water-sample intake were located immediately adjacent to the thalweg, and the height was manually adjusted to sample at approximately $50 \%$ of the stream depth. Water samples were analyzed for TSS concentration using vacuum filtration standard method 2540D (Eaton et al. 1995) with prerinsed, preweighed glass fiber filters of 0.7 $\mu \mathrm{m}$ (0.00003 in).

For the rural and urban sampling locations, 15-minute TSS estimates were derived from 15-minute turbidity measurements using separate turbidity-measured TSS regression relationships developed for the rising and falling limbs of the hydrograph, as described in detail in Ostrowski (2007). These turbidity-measured TSS relationships were based upon paired Nephelometric Turbidity Units and TSS measurements made for 2002 to 2006 WY (rural: 451 paired samples; urban: 428 samples). This rising/falling limb separation integrates the observed changes in particle-size distribution of sediment during storm events (higher percentage of coarser sediments on the rising limb relative to the falling limb, continued suspension of finer silt and clay-size sediments on the falling limb) because infrared backscatter turbidity meters such as the OBS-3 are much more sensitive to clay- and silt-size material than to sandsize material (Lewis 1996). Compared to a single turbidity-TSS relationship, the separate rising/falling limb relationships provided the most accurate prediction of 15-minute TSS from 15-minute turbidity measurements when compared to measured TSS. Sediments loads for a 15-minute period were calculated by multiplying the 15-minute discharge by the 15-minute TSS concentration. Annual sediment loads were calculated as the sum of all 15-minute sediment loads within a water year.

At the forest monitoring location, shallow water flows prevented reliable turbidity measurements. Therefore, sediment loads were estimated using TSS from water samples collected at intervals ranging from one to four days between samples. Methods used for estimating and calculating sediment loads were similar to those used with the MWWTP grab-sample data.

Statistics. The following two approaches were used to test for the presence of a significant trend in sediment load: a seasonal Mann-Kendall test and an ordinary least squares (OLS) regression.

The Mann-Kendall test statistic is a nonparametric test with fewer underlying assumptions on the distribution of the data with a null hypothesis that the data are independent and identically distributed; the alternate hypothesis is that the data follow a monotonic trend over time (Hipel and McLeod 2005; Helsel and Hirsch 1992; Gilbert 1987). The Mann-Kendall statistic calculates the sign of the difference between all pair-wise comparisons of the dependent variable (e.g., annual sediment concentration) from year to year. The summation of the number of positive or negative occurrences 
Table 2

Total and percent of the total observed flow and sediment load from the rural and urban areas of the watershed. Bold values highlight periods where the land use delivers a disproportionately large percent of the total sediment load for the amount of flow delivered from the region. Program 319 practices were installed between 2000 to 2003 in the Paradise Creek watershed.

\begin{tabular}{|c|c|c|c|c|c|c|c|c|c|c|}
\hline \multirow[b]{3}{*}{ Year } & \multicolumn{4}{|l|}{ Rural } & \multicolumn{4}{|l|}{ Urban } & \multicolumn{2}{|l|}{ Total } \\
\hline & \multicolumn{2}{|l|}{ Flow } & \multicolumn{2}{|l|}{ Load } & \multicolumn{2}{|l|}{ Flow } & \multicolumn{2}{|l|}{ Load } & \multirow{2}{*}{$\begin{array}{l}\text { Flow } \\
\text { (ha-m) }\end{array}$} & \multirow{2}{*}{$\begin{array}{l}\text { Load } \\
\text { (t) }\end{array}$} \\
\hline & (ha-m) & (\%) & $(t)$ & (\%) & (ha-m) & (\%) & (t) & (\%) & & \\
\hline 2003 & 280 & 41 & 1,280 & 74 & 410 & 59 & 460 & 26 & 690 & 1,740 \\
\hline 2004 & 280 & 53 & 540 & 90 & 250 & 47 & 60 & 10 & 530 & 600 \\
\hline 2007 & 430 & 77 & 270 & 57 & 130 & 23 & 200 & 43 & 560 & 470 \\
\hline 2008 & 440 & 60 & 220 & 57 & 290 & 40 & 160 & 43 & 730 & 380 \\
\hline
\end{tabular}

in the data record indicates whether the trend is decreasing or increasing. A variance is calculated, and the test statistic is then converted into a $\mathrm{z}$-score to test for statistical significance. Winkler (2004) recommends that the MannKendall test should only be applied to datasets having at least a five-year record.

Streamflow and sediment load in the NWRR, which has dry summers and wet winters, vary widely throughout the year. This seasonality complicates the trend analysis because flow sediment load and sediment concentration do not vary linearly with time when aggregated over short periods such as weekly, biweekly, or monthly data. In addition, the distribution of sediment loading data is not normally distributed and is highly skewed. A Wilcoxon test revealed a significant seasonal effect on sediment load. For this reason, a seasonal Mann-Kendall test statistic was used for detecting a trend. In the seasonal Mann-Kendall test, the statistic is calculated separately for each season, resulting in unique variance structures (Hipel and McLeod 2005; Winkler 2004). The Statistical Analysis Systems (SAS) statistical software package was used for the analysis following Winkler (2004).

When data records were less than seven years in length, significant decreasing trends were calculated by OLS regressions using the SAS statistical software package. Regressions were made between average yearly sediment concentration, calculated by dividing total load for the year by total water volume, and time. All datasets were tested to determine if the assumptions of OLS regression were met using the univariate procedure of SAS and by examining plots of the residuals.

\section{Results and Discussion}

Sediment Load Trends at the Outlet. The yearly sediment loads calculated from the MWWTP grab-sample data varied widely over the 22-year record (figure 3 ). The sediment loads ranged from $45 \mathrm{t}(50 \mathrm{tn})$ in 1994 to $10,600 \mathrm{t}(11,700 \mathrm{tn})$ in 1996 . The peak sediment load in 1996 was caused by an extreme rain-on-snow event, which caused widespread flooding throughout the watershed.The average and median yearly sediment load was $1,500 \mathrm{t}(1,700 \mathrm{tn})$ and $700 \mathrm{t}$ (770 tn), respectively. Table 2 shows that the total load estimated from event-based monitoring data at the watershed outlet was greater than $1,500 \mathrm{t}$ during installation of Program 319 practices and was between 130 and $590 \mathrm{t}$ (140 and $650 \mathrm{tn})$ in subsequent years.

In order to remove the effect of climate variability from the long-term datasets, the total sediment load was normalized by total stream volume for the year to calculate an

\section{Figure 3}

Total flow volume (ha-m) measured at the US Geological Survey monitoring station. Total load at the outlet Paradise Creek watershed calculated from total suspended sediment from Moscow Waste Water Treatment Plant grab samples.

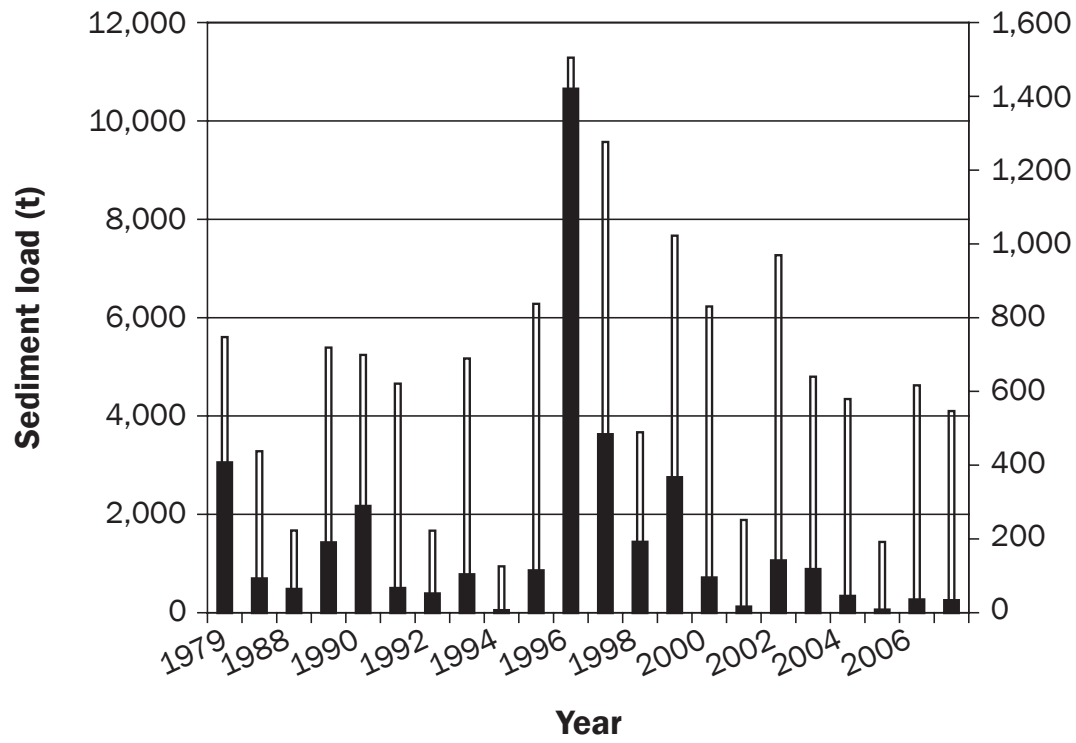

\section{Legend}

Sediment load

$\square$ Total flow 


\section{Figure 4}

Average yearly sediment concentration calculated by dividing total sediment load for the year (in t) by total flow volume for the year (in ha-m) using both the three-day per week grab-sample data for 1979 to 2007 from the Moscow Waste Water Treatment Plant and using the detailed event-based sampling from 2002 to 2008.

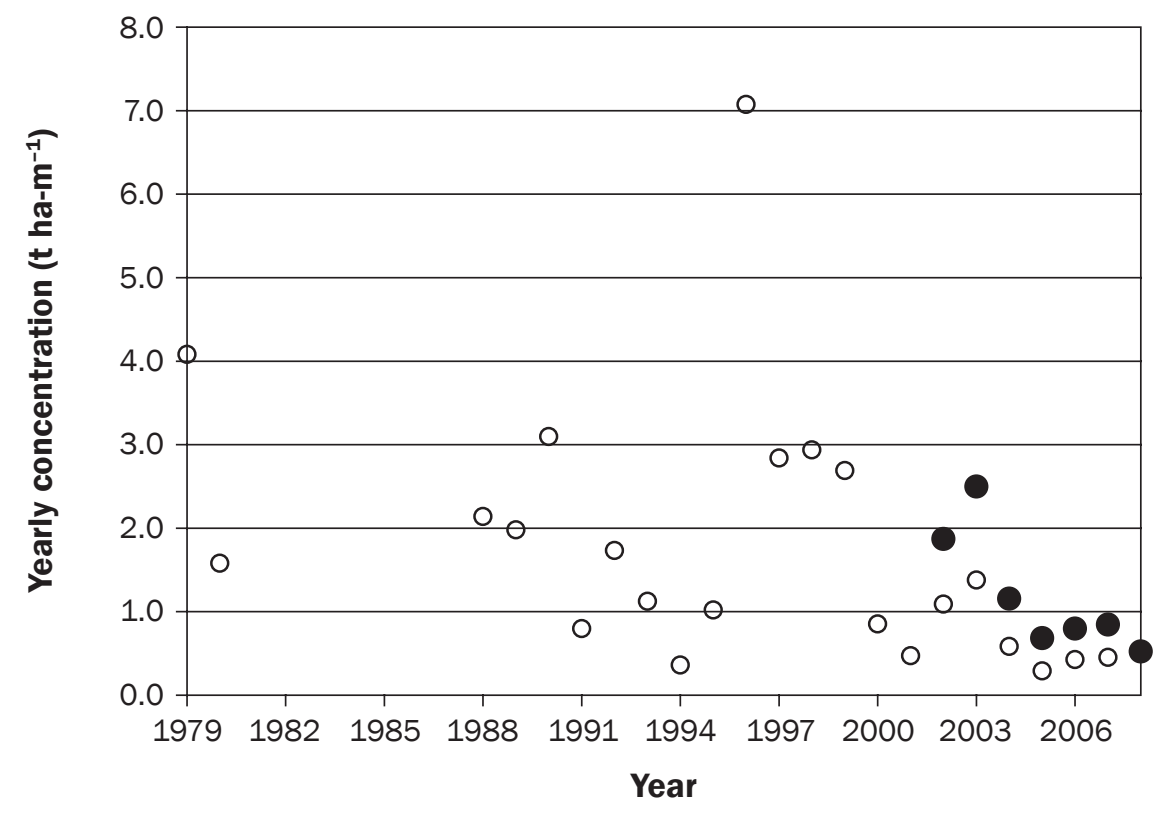

Legend

O Three-day per week sampling

Event-based sampling

annual sediment concentration. Figure 4 shows annual sediment concentration calculated using the MWWTP data and the event-based data. Sediment load estimates using the MWWTP data were consistently less than sediment load estimates using the event-based data. The average underestimation of sediment loads using the MWWTP data over the nine-year period was $47 \%$ with a standard deviation of $9 \%$. The greatest underestimation was $59 \%$ in 2005 , and the least underestimation was $32 \%$ in 2002. This underestimation may be attributed to differences in sample collection methods. First, MWWTP grab samples were collected from the top of the water column, whereas the event-based samples were collected from a location of approximately $50 \%$ of the watercolumn depth. Suspended sediment within the water column is often vertically stratified with an increase in coarser, denser material and higher suspended sediment concentrations with depth (Edwards and Glysson 1998), and this may explain the relative differences between our datasets. Additionally, a greater number of event-based samples were collected relative to the MWWTP grab samples, which likely provided more accurate measurements of peak TSS during extreme flow events (figure 5). For example, the total sediment load calculated from the event-based data for the $2006 \mathrm{WY}$ was based on 246 samples, most of which were concentrated on storm events, whereas the sediment load calculated from the MWWTP data was based on 153 samples taken independent of storm events. Since we observed that the loads from MWWTP grab-sample data were consistently lower than our detailed eventbased load estimations for seven water years, we considered the sediment loads estimated from the MWWTP grab-sample data reliable sources for assessing long-term trends in sediment loading in the PCW.

A long-term decline in average annual sediment concentration is apparent in both the MWWTP data since 1979 and the detailed event-based sampling data over the last nine years (figure 4). The Mann-Kendall test revealed a highly significant decreasing trend in monthly average sediment concentration for the 18 years of long-term monitoring data $(\mathrm{z}$-score $=-8.6414, p<0.0001)$ from 1988 to 2006 . The first two years of data collection were not used because of the large gap in observed data between 1981 and 1988. The decline in average annual sediment concentration measured at the outlet of the watershed with the detailed eventbased sampling data was also significant at a probability level of $0.0510\left(r^{2}=0.5663\right)$ using OLS regression.

Sources of Sediment within the Paradise Creek Watershed. The detailed event-based monitoring network was used to identify where in the PCW the greatest reduction in sediment load was achieved. As seen in figure 6 , the long-term reduction in sediment loads measured at the watershed outlet was caused by a noticeable reduction in sediment loads from the rural region of the watershed. The annual sediment concentrations from the rural region of the watershed dropped from values greater than $2 \mathrm{t} \mathrm{ha}^{-1}\left(0.9 \mathrm{tn} \mathrm{ac}^{-1}\right)$ in the first three years to sediment concentrations consistently below $1 \mathrm{t} \mathrm{ha}^{-1}\left(0.4 \mathrm{tn} \mathrm{ac}^{-1}\right)$ since 2005. This decline in sediment concentration at the rural station was significant $\left(r^{2}=0.7174, p=0.0162\right)$ according to the OLS regression test. In contrast, during the same time period, no noticeable change was observed in the annual sediment concentrations in the urban region of the watershed $\left(r^{2}\right.$ $=0.0309, p=0.7062$ ). Table 2 further illustrates a transition from a condition where a disproportionately high amount of sediment for the relative amount of flow was initially being delivered from the rural region of the PCW for the years 2002 to 2004 to a condition where the urban region appears to be delivering disproportionally high sediment loads to the watershed outlet.

The 1997 PCW TMDL assessment (IDEQ 1997) estimated that $5 \%$ of the total sediment load was contributed by the urban region of the watershed, $88 \%$ was contributed by the rural region, and $7 \%$ was coming from the forested region. However, the sediment loads calculated from the event-based dataset over the last seven years indicate much greater contributions of sediment from the urban region of the watershed (see table 2). The urban region contributed as much as $82 \%$ of the sediment load during 2005 WY. Over the seven-year period of event-based data collection, the urban region contributed on average $43 \%$ of the overall annual sediment loads. Sediment loads from the forested area were negligible compared to sediment loads calculated for urban and rural 


\section{Figure 5}

Measured streamflow and calculated cumulative sediment load measured at the outlet of the entire watershed for the $\mathbf{2 0 0 6}$ water year. Open circles indicate when an event-based sample was taken, and triangles indicate when grab samples were taken.

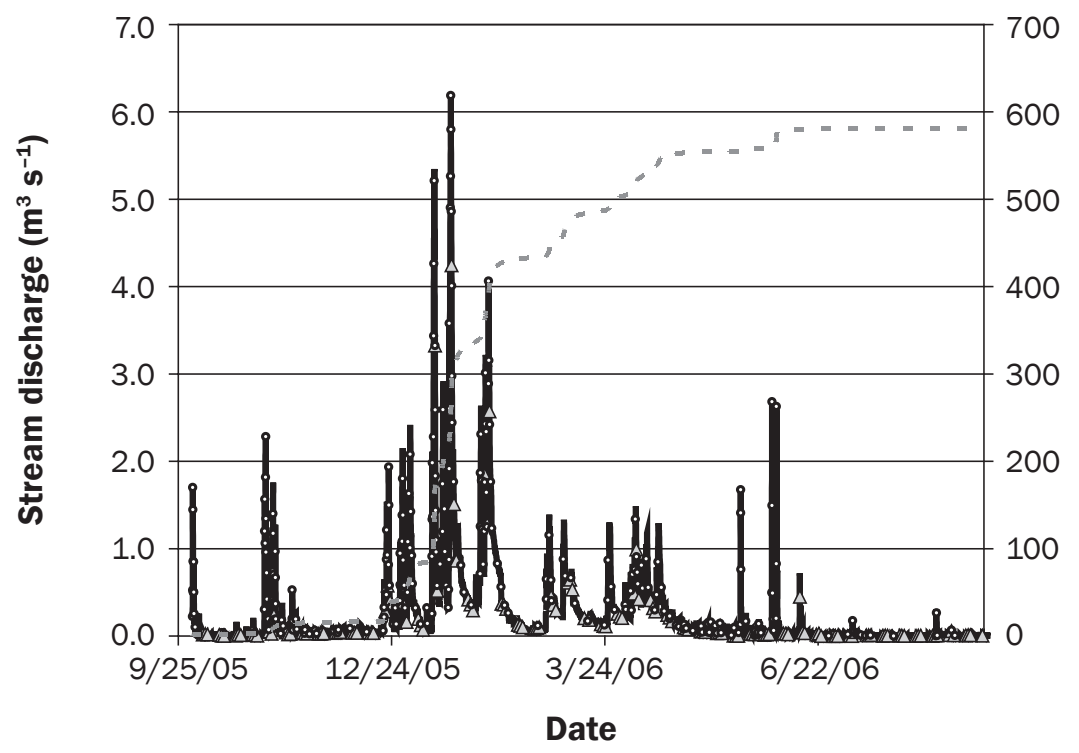

Legend

$$
\begin{array}{cl}
- & \text { Discharge } \\
\triangle & \text { MWWTP grab sample } \\
\text { - } & \text { Event-based sample } \\
-\quad- & \text { Cumulative TSS load }
\end{array}
$$

Note: TSS $=$ total suspended sediment. MWWTP $=$ Moscow Waste Water Treatment Plant.

monitoring stations. In 2006 WY, the total sediment load from the forested catchment was $1 \mathrm{t}$ $\left(0.4 \mathrm{tn} \mathrm{ac}^{-1}\right)$ (data not shown), whereas the sediment load contributions from the rural and urban regions was 230 and 360 t (250 and 400 tn), respectively.

The event-based data also show that runoff rates are consistently greatest in the urban region of the PCW throughout the year (figure 7). The urban region is largely impervious with few infiltration basins to absorb rainfall and/or snowmelt. Therefore, most rainfall events, including those with low rainfall intensities, generate runoff in the urban areas of the PCW and contribute directly to the stream. In contrast, the rural and forested regions of the watershed generally exhibit greater infiltration capacities and more readily absorb and store rainfall delivered during the dry summer and fall months and snowmelt generated in mid to late winter.

Despite only occupying $20 \%$ of the overall watershed, the urban region contributed the greatest volume of water for all months, except January and February. During January and February, the rural areas in the PCW, which occupy $62 \%$ of the watershed, contributed the greatest volume of water (figure 8).

Implications for Effectiveness of Conservation Practices. Detailed PCWmonitoring data show that (1) overall sediment load at the watershed outlet is declining, (2) the decline is due to a decline in the sediment load from the rural region of the watershed, and (3) the relative contribution of sediment from the urban region is greater than previously reported in the PCW TMDL report (IDEQ 1997). It is difficult, however, to pinpoint the primary sources of sediment within the urban region or the most effective management practices in the rural areas. Combining the historical records discussed above, field observations, and monitoring results, we identify three implications of these finding to address CEAP objectives.

First, streambank stabilization, riparian restoration, and gully plugs were not widely implemented before the year 2000 .
Hence, we conclude that long-term declines in sediment loads observed before 2000 in this study and presented by Ebbert and Roe (1998) and McCool and Roe (2005) can be largely attributed to the transition to conservation tillage practices as described by STEEP (2007).

Second, streambank stabilization practices used in the PCW did not reduce downstream sediment loads at the watershed outlet. During the 2000 to 2003 TMDL implementation phase, stream restoration practices focused on $45 \%$ of the total urban stream length, compared to $17 \%$ of the total rural stream length. However, only the rural region experienced declining sediment loads. We note that sediment loads through the urban areas did not increase. In the field of fluvial geomorphology, it is commonly recognized that a stream channel tends toward an equilibrium state, which was originally described by Lane (1955). According to the work of Lane (1955), a decrease in upstream sediment load, without a change in the magnitude of flow or particle size, will lead to increased downstream streambank erosion as the stream tends towards a flatter slope by increasing the overall stream length. Flume studies also have revealed a clear inverse relationship between the sediment load carried by flowing water and the soil detachment (erosion) rate; the cleaner the water, the greater the erosion (Zhang et al. 2009). Thus, a reduction in upslope sediment load from the rural areas conceivably could lead to an increase in downstream streambank erosion. Stream stabilization projects in the urban area may have prevented this increase in erosion. Streambank restoration practices may have reduced the sediment load contribution from a given restored reach. However, we did not measure an effect at the watershed outlet in this study. Riparian restoration likely improved habitat and reduced stream temperatures, but this analysis focuses on sediment.

Third, the average annual sediment loading concentration from the rural region over the last four years appears to have stabilized and is roughly equivalent to the average annual sediment loading concentration from the urban region (figure 9), implying that the sediment transport mechanisms for these years were similar in rural and urban regions. Our research indicates that during these years, upland erosion in the rural region has 


\section{Figure 6}

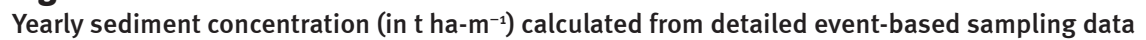
at the rural and urban monitoring stations.

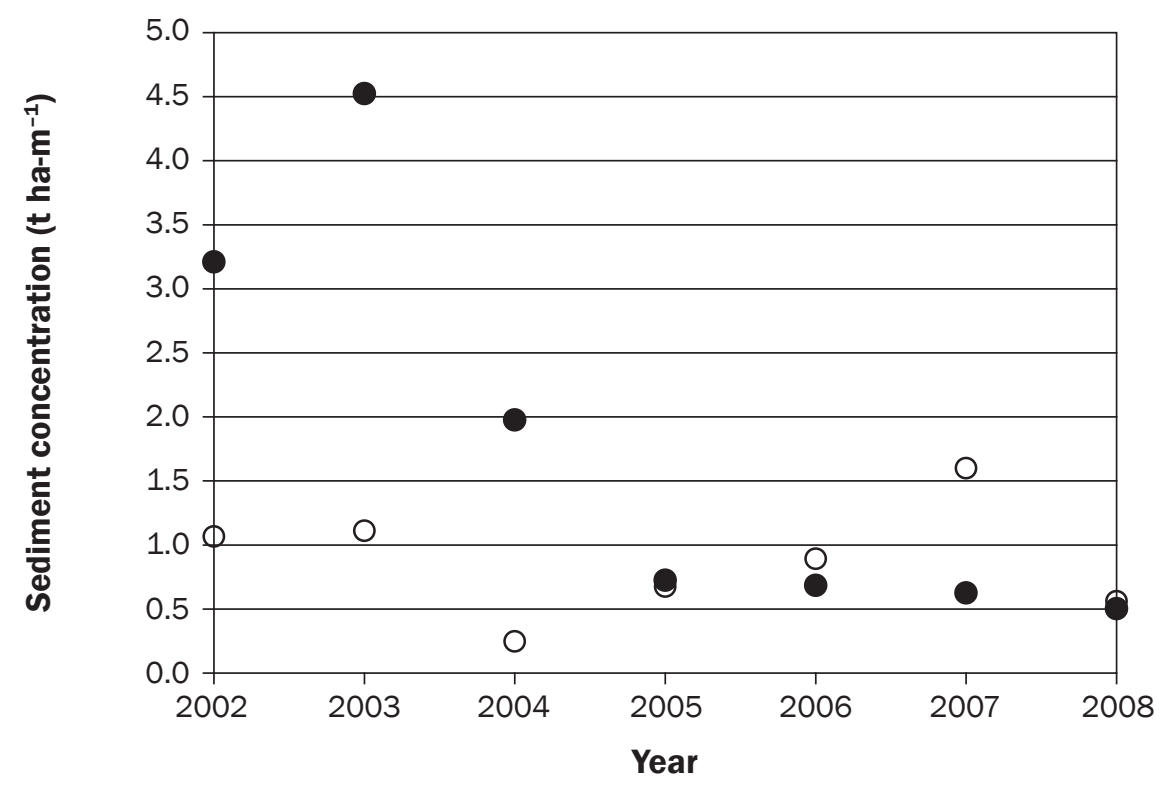

Legend

Rural

O Urban

\section{Figure 7}

Average yearly runoff depth $(\mathrm{mm})$ for the forest, rural, and urban areas in the watershed.

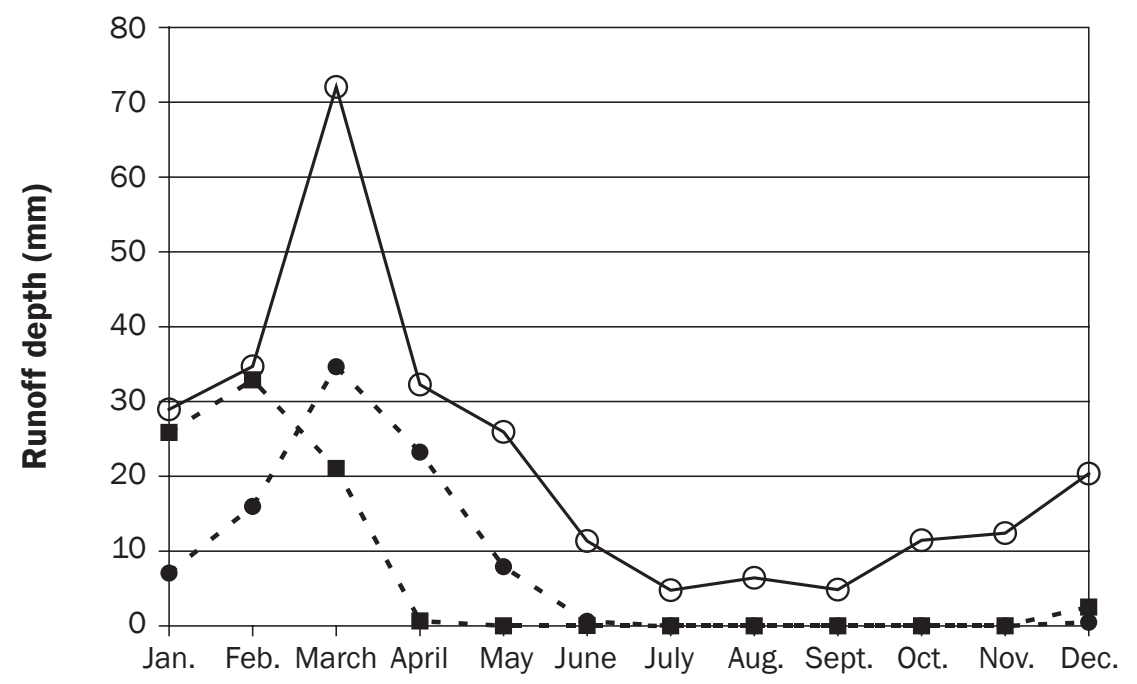

\section{Month}

\section{Legend}

- - Forest

- - - Rural

- Urban been negligible compared to in-stream sediment transport.

We hypothesize that the dominant sediment transport mechanism in the urban region for all seven years (2002 to 2008) and the sediment transport from the rural region for the last four years (2005 to 2008) has followed a transport-limited, flushing process. In transport-limited sediment transport, the total sediment load is determined by flow characteristics, rather than the amount of sediment added to the stream. In this process, sediment stored in the channel from years of excessive erosion is gradually being transported through the stream network. A close linear relationship between flow volume and total sediment load for the urban region, shown in figure 9, confirms the transportlimited process. Four of the sediment loading points from the rural region fall close to the trend line of the urban region. Interestingly, these four points are the loads from the last four years of the study, which suggest that the rural areas may also be transitioning to a more transport-limited condition.

Paradise Creek is known for in-stream deposition of sediment, especially in stream reaches dominated by dense stands of reed canary grass (Phalaris arundinacea L.) (figure 10). Reed canary grass is a large, coarse, perennial grass that reaches 1 to $3 \mathrm{~m} \mathrm{(3.3} \mathrm{to}$ $9.8 \mathrm{ft}$ ) in height, thrives in cool, wet environments, and can quickly establish itself in highly disturbed, nutrient-rich environments (USDA NRCS 2001). It is a very competitive, highly responsive, persistent plant that quickly out competes other herbaceous species by depriving them of light (Lavergne and Molofsky 2004). In stream channels and irrigation canals, reed canary grass will slow the water velocity, leading to increased sediment deposition and reduced conveyance capacities (Hodgson 1968). Farm operators in the PCW have observed extreme deposition in Paradise Creek, which buries tile drain outlets and leads to more frequent periods of overbank flooding. Historic deposition rates can be high. For example, one farm operator dredged a reach of sediment-filled stream channel in 1980, and after 20 years, the same reach of channel was again filled with deposited sediment.

It is possible that the source of much of the sediment load contributed through the urban region of the PCW may be sediment deposited in the stream network several years or potentially decades ago, which is now 


\section{Figure 8}

Average yearly runoff volume in ha-m for the forest, rural, and urban areas in the watershed.

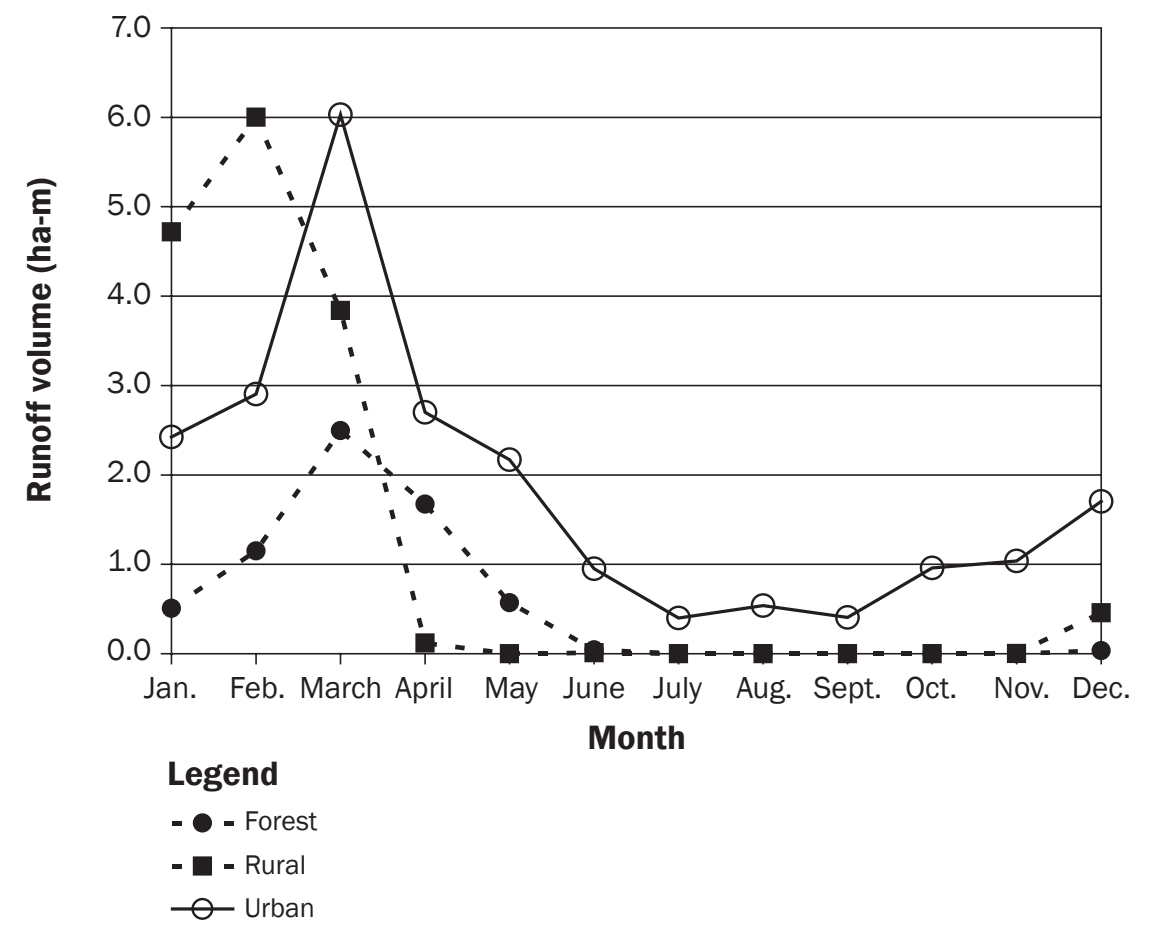

\section{Figure 9}

Total yearly flow volume (ha-m) versus total yearly sediment load $(t)$ calculated from detailed event-based sampling data at the rural and urban monitoring stations.

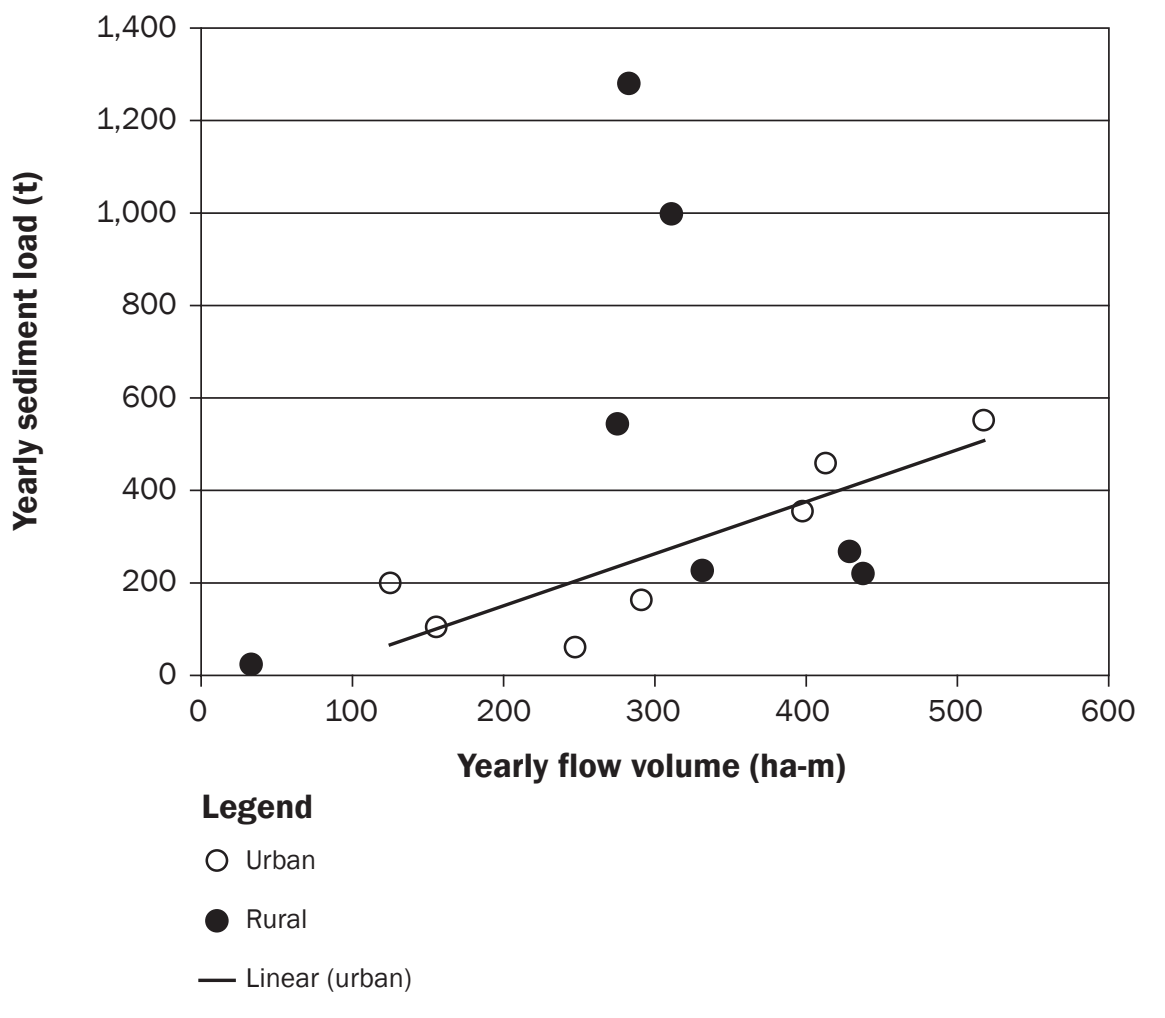

flushing out through the stream network. We have recently begun conducting yearly field campaigns using survey-grade global positioning systems accurate to $2 \mathrm{~cm}(0.8 \mathrm{in})$ to track yearly changes in storage within the Paradise Creek stream network. This added information, along with future in-stream modeling efforts, will help resolve whether in-stream sediment transport is a dominant source of sediment in the watershed.

\section{Summary and Conclusions}

Although the NWRR has a long history of excessive erosion, the long-term monitoring data collected in the PCW indicate that soil and water conservation management in the region has resulted in significantly declining trends in overall sediment load at the outlet of the watershed. Both grab-sample data dating back to 1979 and detailed event-based data collected over the last seven years have significantly declining trends. Detailed monitoring data in the PCW indicate that the reduction can be attributed to improvements made in the rural region of the watershed. A review of previous soil conservation research in the high precipitation zone shows that the reduction in sediment load at the watershed outlet is likely due to the long-term adoption of conservation tillage practices, which exclude the burning of wheat stubble, avoid practicing summer fallow, and minimize tillage erosion. Although there have been many studies that confirm the effectiveness of soil conservation practices from hillslope plots, this research is one of few that can identify a statistically significant decline in sediment loading at the watershed outlet.

Despite substantial streambank stabilization projects that were applied to nearly half of the entire stream length, there were no apparent reductions in sediment loading through the urban section of the PCW. We speculate that much of the current sediment load in the PCW comes from the flushing of sediment stored in stream channels. There is long-term evidence of excessive deposition in stream reaches covered in thick stands of reed canary grass. The lack of published evidence of long-term decline in sediment loading may be largely due to stream sediment storage effects. Future modeling and monitoring research is designed to address the sediment flushing mechanism and the possible implications of the declining upstream sediment loads on downstream streambank erosion. 


\section{Figure 10}

Paradise Creek watershed stream channel taken on May 19, 2005. Notice the dense cover of reed canary grass within the stream channel. The reed canary grass stands often reach to greater than $2 \mathrm{~m}$ in height.

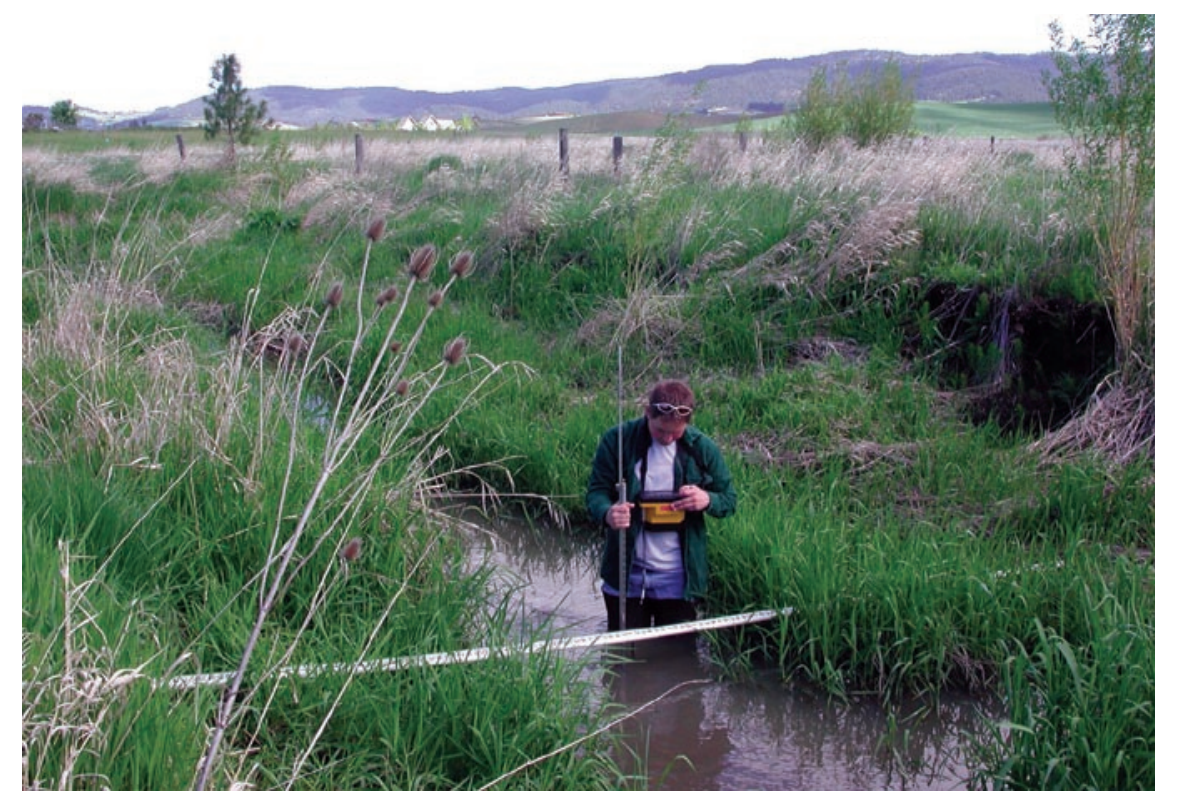

\section{Acknowledgements}

Authors thank landowners in the PCW for access to their properties during this study, the city of Moscow for cooperation in sharing monitoring data, and Nairanjana Dasgupta for assistance with the SAS programming. This study was funded through the USDA Cooperative State Research, Education, and Extension Service Conservation Effects Assessment Program (grant 2004-48619-03119).

\section{References}

Barker, R.J. 1981. Soil Survey of Latah County Area, Idaho. USDA Soil Conservation Service.

Busacca, A.J. 1989. Long quaternary record in eastern Washington, USA interpreted from multiple buried paleosols in loess. Geoderma 45:105-122.

Eaton, A.D., L.S. Clesceri, and A.E. Greenberg, ed. 1995 Standard Methods for the Examination of Water and Wastewater. 19th Edition.

Ebbert, J.C., and R.D. Roe. 1998. Soil erosion in the Palouse River Basin: Indications of improvement. US Geological Survey Fact Sheet FS-069-98. http://wa.water.usgs. gov/pubs/fs/fs069-98/.

Edwards, T.K., and G.D. Glysson. 1998. Field methods for measurement of fluvial sediment: Book 3, Applications of hydraulics, Chapter C2,Techniques of water-resources investigations of the United States Geological Survey.

Gilbert, R.O. 1987. Statistical Methods for Environmental Pollution Monitoring. New York: John Wiley \& Sons.

Helsel, D.R., and R.M. Hirsch. 1992. Statistical methods in water resources. Studies in Environmental Science 49:323-355.
Hipel, K.W., and A.I. McLeod. 2005. Time Series Modeling of Water Resource and Environmental Systems. Electronic reprint of out-of-print text originally published in 1994, 853-872. http://www.stats.uwo. ca/faculty/aim/1994Book/.

Hodgson, J.M. 1968. Chemical control of reed canary grass on irrigation canals. Weed Science 16(4):465-468.

IDEQ (Idaho Division of Environmental Quality). 1997. Paradise creek TMDL: Water Body Assessment and Total Maximum Daily Load. Lewiston, ID: Idaho Department of Environmental Quality.

Kaiser, V.G. 1961. Historical land use and erosion in the Palouse-A Reappraisal. Northwest Science 35(4):139-153.

Kaiser,V.G. 1967. Soil erosion and wheat yields in Whitman County, Washington. Northwest Science 41(2):86-91.

Lane, E.W. 1955. The importance of fluvial morphology in hydraulic engineering. Proceedings of the American Society of Civil Engineers 81(745):1-17.

Lavergne, S., and J. Molofsky. 2004. Reed canary grass (Phalaris arundinacea) as a biological model in the study of plant invasions. Critical Reviews in Plant Sciences 23(5):415-429.

Lewis, J. 1996. Turbidity-controlled suspended sediment sampling for runoff-event load estimation. Water Resources Research 32(7):2299-2310.

McCool, D.K., and R.D. Roe. 2005. Long-term erosion trends on cropland in the Pacific Northwest. Presented at the 2005 Pacific Northwest Section Meeting of the American Society of Agricultural Engineers, Lethbridge, Alberta, Canada, Sept. 22-24, 2005. St. Joseph, MI: American Society of Agricultural Engineers Section Meeting Paper No. PNW05-1002, 17.
McDaniel, P.A., R.W. Gabehart, A.L. Falen, J.E. Hammel, and R.J. Reuter. 2001. Perched water tables on Argixeroll and Fragixeralf hillslopes. Soil Science Society of America Journal 65:805-810.

Newson, J. 2007. Measurement and Modeling of Sediment Transport in a Northern Idaho Stream. MS Thesis University of Idaho, Moscow.

Ostrowski, K.M. 2007. Effect of particle size distribution on sediment loading in a mixed-land use watershed in northern Idaho. PhD dissertation, University of Idaho, United States - Moscow, Idaho.

PCWAG (Paradise Creek Watershed Advisory Group). 1999. Paradise Creek total maximum daily load implementation plan. Moscow, ID: Paradise Creek Watershed Advisory Group, Latah Soil and Water Conservation District.

PCWAG. 2004. Paradise Creek total maximum daily load implementation project. Moscow, ID: Paradise Creek Watershed Advisory Group, Latah Soil and Water Conservation District and Palouse-Clearwater Environmental Institute.

STEEP (Solutions to Environmental and Economic Problems). 2007. STEEP Impact Assessment. Solutions to Environmental and Economic Problems (STEEP) Technical Report. http://pnwsteep.wsu.edu/STEEP_ impact_summary_2007.pdf.

USDA. 1978. Palouse cooperative river basin study. Economic, Statistics, and Cooperative Service, Forest Service, and Soil Conservation Service. Washington, DC: USDA.

USDA NASS (National Agricultural Statistics Service). 2009. Crop yield records by state and county. USDA National Agricultural Statistics Service. http://www.nass.usda. gov/Data_and_Statistics/Quick_Stats/index.asp.

USDA NRCS (Natural Resources Conservation Service). 2001. Biology, History, and Suppression of Reed Canarygrass (Phalaris arundinacea L.). USDA Natural Resources Conservation Service, Boise ID. Technical Note Plant Materials No. 40.

Winkler, S. 2004. A user-written SAS program for estimating temporal trends and their magnitude. Technical Publication SJ2004-4 of the St. Johns River Water Management District. http://sjr.state.fl.us/ technicalreports/tpubs1.html\#2004.

Zhang, G.Y. Liu, Y. Han, and X.C. Zhang. 2009. Sediment transport and soil detachment on steep slopes: II. Sediment Feedback Relationship. Soil Science Society of America Journal 73:1298-1304. 